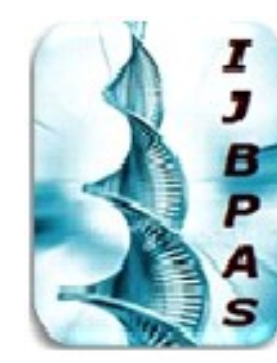

International Journal of Biology, Pharmacy and Allied Sciences (IJBPAS) 'A Bridge Betuen caboratory and QRender'

WwW.iibpas.com

\title{
RELATIONSHIP BETWEEN CELL PHONE OVER USE AND INTERNET ADDICTION AMONG NURSING STUDENTS AT SELECTED COLLEGE, CHENGALPATTU DISTRICT
}

\section{RAMYA RATHI DEVI $M^{1}$, USHAPRIYA $M^{* 2}$, TAMILSELVI $S^{2}$ AND PRIYA ${ }^{2}$}

1: Associate Professor, SRM College of Nursing, SRM Institute of Science and Technology, SRM Nagar, Kattankulathur, Chennai, Kancheepuram TamilNadu - 603203, India 2: Assistant Professor, SRM College of Nursing, SRM Institute of Science and Technology, SRM Nagar, Kattankulathur, Chennai, Kancheepuram, TamilNadu - 603203, India

*Corresponding Author: M.Ushapriya: E Mail: ushapriyansg@gmail.com;

Phone No.: 8940597167

Received 19 ${ }^{\text {th }}$ Oct. 2020; Revised 10 ${ }^{\text {th }}$ Nov. 2020; Accepted $20^{\text {th }}$ Nov. 2020; Available online $1^{\text {st }}$ Aug. 2021 https://doi.org/10.31032/IJBPAS/2021/10.8.5563

\begin{abstract}
Cell phones have turned out to be a nearly vital portion of day-to-day life. Cell phone overuse has become wide problem in the world. Internet Addiction is a recent occurrence that looms to advance into a main communal well-being problem in the near forthcoming in world. It is persuading the life of the public specifically students. Aims: 1) To assess the level of cell phone overuse and internet addiction among nursing students selected college. 2) To determine the relationship between cell phone overuse and internet addiction among nursing students selected college. 3) To associate the cell phone overuse and internet addiction among nursing students at selected college. Materials and Methods: Research approach was quantitative and design was descriptive research design. The samples were elected by means of convenient sampling method and comprised of 231 nursing students. The instruments of the study were: Section A - Demographic variables; Section B - Cell phone Overuse Scale (COS) was used to assess the mobile phone addiction. It was established by Jenaro et al.; Section C - Internet Addiction Test (IAT) scale to evaluate the internet addiction among nursing students, devised by Dr. Kimberly Young. Both the scale encompasses of 20 items. Information collected were analysed by using descriptive and inferential statistics. Results: The results show that there is high significant correlation between "Cell Phone Overuse" and "Internet Addiction". Conclusion: Nursing students have to recognize the significance of Cell phone use as
\end{abstract}


well as for beginning and upholding public effort to avoid the damaging effects of overuse and internet addiction.

Keywords: Cell phone overuse, Internet addiction, world, Nursing students

\section{INTRODUCTION}

Cell phone use has reached great growth in India and in the world. Cell phone overuse is also called as smartphone addiction, mobile phone overuse, or smartphone overuse. Recent research found that opposing effect of abusing technology, "cell phone overuse" has been projected as a subsection of arrangements of "digital addiction", or "digital dependence", showing growing pattern of obsessive behaviour among handlers of technological devices [1]. Excess use of cell phones can be connected with undesirable consequences on psychological and bodily health, in adding to having an effect on in what way handlers interact communally [2]. Nowadays, communication with societal mass media be indebted to the usage of cell phone, which is well-thoughtout as the utmost prevalent and overriding culture in globally [3].

Approximately seven hundred million internet users are present in India across the country in 2020. By 2025 it is predicted that this may increase to nine hundred and seventy four million users which denotes a huge marketplace probable in network facilities for South Asian country. India has been graded as the $2^{\text {nd }}$ largest online marketplace in the year 2019.
The quantity of network users was predicted to rise in equally in rural and urban areas [4].

In current years, cell phone plays an vital part in telecommunications all over globally, since of price of cell-phone usage drops and use of phone increases [5, 6]. Internet addiction too disturbs individuals academic and proficient development and family relationships negatively $[7,8]$.

Nastaran Norouzi Parashkouh et al, conducted a cross sectional study to evaluate the prevalence of internet and mobile phone addiction among 581 high school Iranian students. Results showed that $53.7 \%, 37.5 \%$ and $8.8 \%$ which meant normal, mild and moderate level of internet addiction. The mean score of COS was $55.10 \pm 19.86$ showed high, moderate and low level of mobile phone addiction which concluded that percentage of cell phone and internet addiction were high among study participants [9].

\section{METHODOLOGY}

Quantitative research approach and design was descriptive research design was used. Study variables were level of cell phone overuse and internet addiction while the demographic variables are age, Gender, Course, Year of the study, Place of 
Residence, Sim Card, Type of Social Network and Number of hours spent on the internet / Day. The nursing students who satisfied the inclusion criteria were selected as sample. The samples were elected by means of convenient sampling method and comprised of 231 nursing students. The instruments of the study were: Section A Demographic variables; Section B - Cell phone Overuse Scale (COS) was used to assess the mobile phone addiction. It was established by Jenaro et al. ; Section C Internet Addiction Test (IAT) scale to evaluate the internet addiction among nursing students, devised by Dr. Kimberly Young. Both the scale encompasses of 20 items. The content of the instrument was recognized on the basis of views of Nursing experts. Recommendations were included in the demographic variable tool. Tool reliability was recognized by test retest technique for and the ' $r$ ' value was 0.88 . Information collected were analysed by using descriptive and inferential statistics.

\section{ETHICAL CONSIDERATIONS}

The proposal was accepted by the dissertation committee of SRM College of Nursing, SRM IST Kattankulathur, Chengalpattu District. Guarantee was given to the samples that anonymity of every individual will be kept confidential and they are allowed to withdraw from the study at any time. The investigators explained the aims and methods of data collection and particulars about the study were described to the samples. The confidentiality about the data and finding were assured to the participants.

\section{RESULTS}

Table 1 shows that $40.3 \%$ of nursing students were in the age of 19 and 20 years, $91.8 \%$ of students were females, majority $81.4 \%$ of students were studying in the B. Sc Nursing course, $30.7 \%$ of them were in first year, most of them 55.8\% resides in hostel, $61.5 \%$ of students use only one SIM card, $72.7 \%$ of students use WhatsApp as their social network and $51.1 \%$ students spend $1-2$ hours of time in the internet.

Table 2 shows that $58.4 \%$ belongs to moderate problematic cell phone overuser, $31.7 \%$ of students were mild problematic user, $3 \%$ of students belongs to severe problematic user category and $0.9 \%$ are not a problematic user.

Table 3 analysis reveals that 48 (20.8\%) nursing students have no internet addiction; $150(64.9 \%)$ nursing student's mild internet addiction; 33 (14.3\%) nursing students have moderate internet addiction and none of them is severely addicted.

The Table 4 analysis p-value in the table above is 0.000 which is less than 0.01 and hence we conclude that the correlation coefficient is highly significant at $1 \%$ level of significance. Therefore we can conclude that there is high significant correlation 
between "Internet Addiction" and "Cell Phone Overuse".

Analysis depicts that the p-values corresponding to the demographic variables "Age, Course and No. of Hours Spent on Internet/Day" are highly significant (since the $p$ values are less than 0.01 ) at $1 \%$ level and hence we can say that "Age, Course and No. of Hours Spent on Internet/Day" are significantly associated with "Level of Cell Phone Overuse". All other variables are not significant at 5\% level since the pvalues are not less than 0.05 .

Analysis depicts that the p-value corresponding to the demographic variable
"No. of Hours Spent on Internet/Day" is highly significant (since the $\mathrm{p}$ value is less than 0.01 ) at $1 \%$ level and hence we can say that "No. of Hours Spent on Internet/Day" is significantly associated with "Level of Internet Addiction". Similarly, the p-value corresponding to the demographic variable "Gender" is significant (since the $\mathrm{p}$ value is less than 0.05 ) at $5 \%$ level and hence we can say that "Gender" is significantly associated with "Level of Internet Addiction". All other variables are not significant at 5\% level since the p-values are not less than 0.05 .

Table 1: Frequency and percentage distribution of demographic variables among nursing students $(\mathrm{N}=\mathbf{2 3 1})$

\begin{tabular}{|c|c|c|c|c|}
\hline S. No. & Demographic Variables & Class & No. of Students & Percentage \\
\hline \multirow{5}{*}{1} & \multirow{5}{*}{ Age in years } & 17- 18 & 81 & $35.1 \%$ \\
\hline & & 19-20 & 93 & $40.3 \%$ \\
\hline & & 21-22 & 50 & $21.6 \%$ \\
\hline & & 23-24 & 4 & $1.7 \%$ \\
\hline & & $>24$ & 3 & $1.3 \%$ \\
\hline \multirow{2}{*}{2} & \multirow{2}{*}{ Gender } & Male & 19 & $8.2 \%$ \\
\hline & & Female & 212 & $91.8 \%$ \\
\hline \multirow{4}{*}{3} & \multirow{4}{*}{ Course } & DGNM & 37 & $16.0 \%$ \\
\hline & & B. Sc. (N) & 188 & $81.4 \%$ \\
\hline & & P.BB.Sc. (N) & 2 & $0.9 \%$ \\
\hline & & M. Sc. (N) & 4 & $1.7 \%$ \\
\hline \multirow{4}{*}{4} & \multirow{4}{*}{ Year of Study } & I Year & 71 & $30.7 \%$ \\
\hline & & II Year & 49 & $21.2 \%$ \\
\hline & & III Year & 64 & $27.7 \%$ \\
\hline & & IV Year & 47 & $20.3 \%$ \\
\hline \multirow{2}{*}{5} & \multirow{2}{*}{ Place of Residence } & Hostel & 129 & $55.8 \%$ \\
\hline & & Home & 102 & $44.2 \%$ \\
\hline \multirow{2}{*}{6} & \multirow{2}{*}{ SIM Card } & One & 142 & $61.5 \%$ \\
\hline & & More than One & 89 & $38.5 \%$ \\
\hline \multirow{7}{*}{7} & \multirow{7}{*}{ Type Of Social Network } & WhatsApp & 168 & $72.7 \%$ \\
\hline & & Face book & 18 & $7.8 \%$ \\
\hline & & Instagram & 6 & $2.6 \%$ \\
\hline & & Messenger & 3 & $1.3 \%$ \\
\hline & & Others & 5 & $2.2 \%$ \\
\hline & & All the Above & 24 & $10.4 \%$ \\
\hline & & None of the above & 7 & $3.0 \%$ \\
\hline \multirow{5}{*}{8} & \multirow{5}{*}{$\begin{array}{l}\text { Number of Hours Spent on the } \\
\text { Internet/Day }\end{array}$} & $1-2 \mathrm{Hrs}$ & 118 & $51.1 \%$ \\
\hline & & 3-4Hrs & 63 & $27.3 \%$ \\
\hline & & 5-6Hrs & 22 & $9.5 \%$ \\
\hline & & $>6 \mathrm{Hrs}$ & 23 & $10.0 \%$ \\
\hline & & $<1 \mathrm{hr}$ & 5 & $2.2 \%$ \\
\hline
\end{tabular}


Table 2: Assessment of level of cell phone overuse among nursing students $(\mathrm{N}=\mathbf{2 3 1})$

\begin{tabular}{|c|c|c|c|}
\hline S. No. & Level of Cell Phone Overuse & No of Students & Percentage \\
\hline 1 & Not a Problematic user & 2 & $\mathbf{0 . 9 \%}$ \\
\hline 2 & Mild Problematic user & 87 & $37.7 \%$ \\
\hline 3 & Moderate Problematic user & 135 & $\mathbf{5 8 . 4 \%}$ \\
\hline 4 & Severe Problematic user & 7 & $\mathbf{3 . 0 \%}$ \\
\hline \multicolumn{2}{|c}{ Total } & 231 & \\
\hline
\end{tabular}

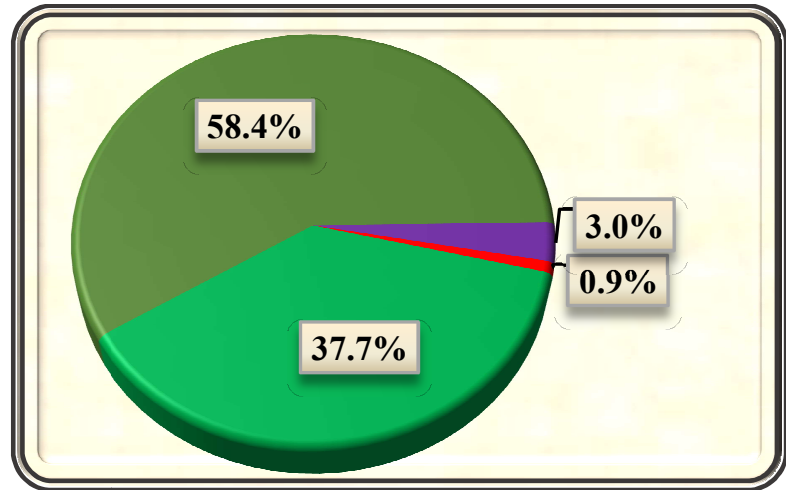

Table 3: Assessment of level of internet addiction among nursing students ( $N=231)$

\begin{tabular}{|c|c|c|c|}
\hline S. No. & Level of Internet Addiction & No of Students & Percentage \\
\hline 1 & No Addiction & 48 & $20.8 \%$ \\
\hline 2 & Average Addiction & 150 & $64.9 \%$ \\
\hline 3 & Moderate Addiction & 33 & $14.3 \%$ \\
\hline 4 & Severe Addiction & 0 & $0.0 \%$ \\
\hline \multicolumn{2}{|r}{} \\
\hline
\end{tabular}

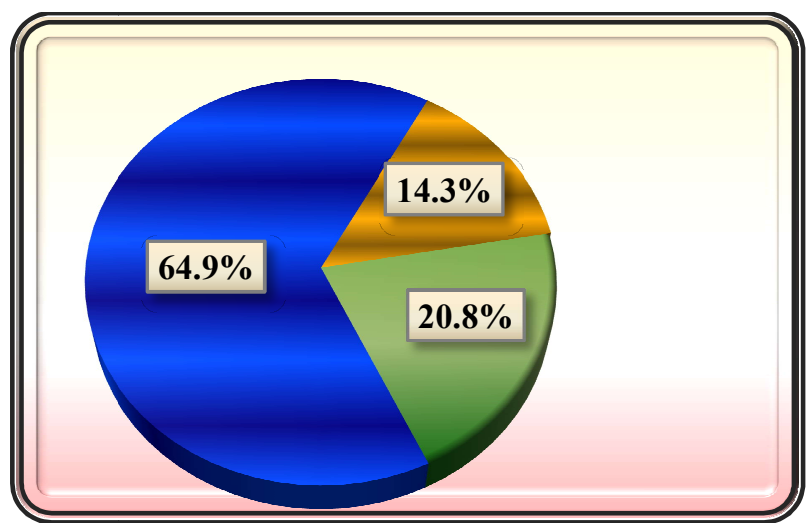

Table 4: Correlation between Cell Phone Overuse and Internet Addiction among nursing students $(\mathbf{N}=231)$

\begin{tabular}{|c|c|c|c|}
\hline S. No. & Variables & Pearson's Correlation ( r ) & P-Value \\
\hline 1 & Internet Addiction & 0.437 & $0.000 * *$ \\
\hline 2 & Cell Phone Overuse & & 0 \\
\hline
\end{tabular}

\section{DISCUSSION}

Cell phones presently rule individuals lives and attention owing to their augmented modest and performance. Though, the adverse facets of cell phone use, such as cell phone addiction, have newly been took up [10].
Analysis reveals that $58.4 \%$ belongs to moderate problematic cell phone over user, $31.7 \%$ of students were mild problematic user, $3 \%$ of students belongs to severe problematic user category and $0.9 \%$ are not a problematic user. The results of the current study are reliable with 
Suliman S Aljomaa et al., conducted the study on smartphone addiction among 416 university students and Outcomes disclosed that dependence percentage among students was $48 \%$ [11] and 48 (20.8\%) nursing students have no internet addiction; 150 $(64.9 \%)$ nursing students mild internet addiction; 33 (14.3\%) nursing students have moderate internet addiction and none of them is severely addicted. Sharma B et al, conducted a cross-sectional study aiming to evaluate the incidence of internet addiction and find its related aspects among 1304 undergraduates. Results showed that prevalence of internet addiction was found to be $44 \%$ [12].

\section{CONCLUSION}

Use of cell phone and internet addiction for several hours has become common in college students. Nursing students has to realize the importance of cell phone use as well as for beginning and sustaining public effort to avoid the damaging things of overuse.

\section{ACKNOWLEDGEMENT}

Investigators thank the Dean and nursing students for their support and cooperation

\section{Conflicts of interest}

- No conflicts of interest.

\section{Authors funding}

- Self.

\section{REFERENCES}

[1] Rubio, Gabriel; Rodríguez de Fonseca, Fernando; De-Sola Gutiérrez, Jose, "Cell-Phone Addiction: A Review". Frontiers in Psychiatry, 2016, 175.

[2] https://en.wikipedia.org/wiki/Proble matic_smartphone_use

[3] Prabhudesai Arun AP. Statistical Report on Internet and Mobile Addiction. Internet and Mobile Association of India. 26 Jan 2010; 25(2). Retrieved from http://socio.ch/mobile/tgeser2.pdf

[4] https://www.statista.com/statistics/2 55146/number-of-internet-users-inindia/

[5] Roberts JA, Yaya LH, Manolis C. The invisible addiction: cell-phone activities and addiction among male and female college students. J Behav Addict. 2014; 3(4): 254-65.

[6] Tavakolizadeh J, Atarodi A, Ahmadpour S, Pourgheisar A. The prevalence of excessive mobile phone use and its relation with mental health status and demographic factors among the students of Gonabad University of medical sciences in 2011 - 2012. Razavi Int J Med. 2014; 2(1): e15527.

[7] Mazhari S. The prevalence of problematic internet use and the 
related factors in medical students, kerman, Iran. Addict Health. 2012; 4(3-4): 87-94.

[8] Ahmadi K. Internet addiction among Iranian adolescents: a nationwide study. Acta Med Iran. 2014; 52(6): 467-72.

[9] https://www.researchgate.net/public ation/304245355_Internet_and_Mo bile_Phone_Addiction_among_Hig h_School_Students_A_Cross_Secti onal_Study_from_Iran

[10] https://bmcpsychiatry.biomedcentr al.com/articles/10.1186/s12888019-2170-zZ

[11] https://www.sciencedirect.com/sci ence/article/abs/pii/S07475632163 02126

[12] http://www.journaldmims.com/arti cle.asp?issn $=09743901 ;$ year $=2018$ ;volume $=13$; issue $=2$; spage $=95 ;$ epage $=99 ;$ aulast $=$ Sha rma 